\section{Creationism and common sense}

SIR--While I take exception to the view held by Reginald T. Chelvam (Nature 331, $10 ; 1988)$, I will agree that "common sense" did not play a part in the Supreme Court's decision. "Clear thinking" won the day. Chelvam's "common sense" is that of a zealot. Common sense, to the general public, would accept that creation science is the valid competing scientific theory that rightly disproves or opposes darwinism. That is patently false and demonstrates the public unfamiliarity with either. Whereas darwinism is only a theory and lacks much evidence that it predicts should exist, there are opposing theories that are scientific and not creationist (that is, not based on the assumption of God's existence). Those are the theories that should be taught in opposition to Darwin's theory of evolution.

The cause of this dilemma is that the public perceives that because the Constitution separates church and state, such a schism must apply in science also, as if the Constitution were itself "holy scripture". (This not to say that the Constitution has no merit; it is the last word when it comes to governmental processes, not physical ones. One cannot extrapolate its statements indiscriminately.) That extrapolation is false. Science and religion need not be an "either/or" proposition. Scientific inquiry cannot presume the existence of God as that would be self-contradictory, but such thought does not require denying the existence of God.

29 Park Drive, Apt 1,

Boston, Massachusetts 02215, USA

SIR-R.T. Chelvam takes issue with your leading article "Setback for creation science", but entirely misses the point. Our current understanding of evolution, based on extensive experiment, threatens only the religions of those whose beliefs tend towards idolatry of ancient texts. It is certainly true that many eminent scientists of the past and present believe in the same creator as the 'creation scientists'; the disagreement comes in the evolution of these beliefs. Scientists, whether with or without a degree in science, are committed to understanding our Universe, and its past, by experiment. As this understanding increases, old notions evolve into more appropriate views. On the other hand, 'creation scientists' are committed to imposing their belief in biblical inerrancy (usually applied only to the first creation story in Genesis) on an unsuspecting public. By fraudulently depicting evolution as the converse of creation, and then appealing to the public's sense of fair play, they have tried to get their religious views into school science teaching. They have failed; that, as you pointed out in an earlier leading article (Nature 327, 643; 1987), is the significance of the US Supreme Court's decision against Louisiana's "Balanced Treatment Act".

Religious citizens can take heart from the Supreme Court's decision; our understanding that all life forms are descended from a single progenitor is no more the death knell of religion than was the destruction of the belief in a geocentric universe in the sixteenth century. Those who would legislate religious beliefs would do well to consider the thoughts of Thomas Paine. As he pointed out in The Rights of Man (1787), such legislation usually confuses the mortal who worships and the immortal who is worshipped, and often demeans the latter. "Were a bill brought into parliament entitled 'An act to tolerate or grant liberty to the Almighty to receive the worship of a Jew or Turk' or 'to prohibit the Almighty from receiving it', all the men would startle, and call it blasphemy."

Stonybrook Apiary,

Pittstown, New Jersey 08867, USA

Sir--Chelvam ${ }^{1}$ attributes to me, without citation, remarks on molecular homology and its bearing on darwinism that he believes give support to creationism. I am said to have "referred to molecular homology (a latter-day prop of darwinism) as 'anti-knowledge' generating "antitheory" and to "slop" in the data of molecular homology which have been "massaged with evolutionary theory." Leaving aside the source or accuracy of these quotations, their use in this context betrays a misunderstanding of the role of homology in evolutionary biology that cannot go unchallenged.

Common descent provides an explanation for homology, and this is the only sense in which Darwin appealed to homology: "On this same view of descent with modification, all the great facts of Morphology become intelligible, - whether we looked to the same pattern displayed in the homologous organs . . . of the different species of a class; or to the homologous parts constructed on the same pattern in each individual" theory, unity of type [homology] is explained by unity of descent". As homology is "always an inference, never an observation", it is plainly wrong to see the inference of common descent as a prop whose removal could affect the status of evolutionary theory.

Molecular homology, between aminoacid or nucleotide sequences, differs from classical homology in that its observational base has become statistical, and some molecular biologists have been castigated ${ }^{4}$ for conflating the observation of statistically significant similarity with the inference of relation through common ancestry. That may betray "muddy thinking"" but it is not "slop" and it has no bearing whatever on the truth of descent with modification.

Chelvam asserts that "we are drowning" in evidence against darwinism. He cites nothing beyond the remarks attributed to me. It seems possible that he confuses two theories under the name of darwinism, the general theory of common ancestry or descent with modification, and Darwin's special theory of mechanism, natural selection. If he knows of evidence inconsistent with the general theory of common descent, he should tell us what it is. I know of none.

\section{Department of Palaeontology,}

British Museum (Natural History), London SW7 5BD, UK

1. Nature 331, 10 (1988)

2. Darwin, C.R. On the Origin of Species, 456; 206 (John Murray, London, 1859).

Van Valen, M. Natur

305, $664(1983)$

4. Reeck, G.R. et al. Cell 50, 667 (1987).

\section{Cup that cheers}

SIR-Although a current study ${ }^{1}$ shows that the aluminium level in infused tea is not after all as high as had earlier been reported $^{2}$, occasional reports of negative effects of tea-drinking ${ }^{3,4}$ must not be generalized as in most cases follow-up clinical studies are lacking. Nutritional and therapeutic values of tea are well documented $^{5}$, and an international seminar in China recently stressed the importance of tea in improving human health. The beneficial effects of tea are mostly due to interactions between a number of compounds of tea infusions ${ }^{6}$, and a single compound may not be of consequence. For example, clinical studies show that the complex tea pigments are effective against cardiac diseases such as arrhythmia and atherosclerosis; black tea brew provided with 1-2 parts per million fluoride increases fluoride uptake ${ }^{8}$, and may thus help in preventing dental caries ${ }^{9}$. Despite some negative findings of a speculative nature, tea continues to cheer people the world over!

Tea Research Association,

B. BANERJEE

Nagrakata,

West Bengal 735225, India

1. Fairweather-Tait, S.J., Moore, G.R. \& Fatemi, S.E.J. Nature 330, 213 (1987)

Corriat, A.M. \& Gillard, R.D. Nature 321, 570 (1986)

Morton, J. Q. J. Crude Drug Res. 12, 1829 (1972)

Kapadia, G Carcinogenesis and Mutagenesis in Environment Vol 2. (CRC, Baton Rouge, 1983).

Das, D.N., Ghosh, J.J., Bhattacharyya, K.C. \& Guha, B.C Indian J. appl. Chem. 28, 15 (1968)

6. Stagg, G.V. \& Millin, D.J. J. Sci. Food Agric. 26, 1439 (1975)

Xia Shunying, Int. Symp. Tea Quality Hum. Hith. 134 (1987).

Karunanayake, E.H., Mahadeva, K., Weerakoon, S.N. \& Wickremasingha, R.L. Tea Q., 43, 111 (1972).

9. Yu Xingfu Int. Symp. Tea Quality Hum. Hlth. 157 (1987). 